Neuroepidemiology 2009;32:164

DOI: $10.1159 / 000184749$

\section{A Medical Enigma: Persons with Down Syndrome Do Not Develop Medulloblastoma}

\author{
D. Satgé ${ }^{\mathrm{a}}$, C.H. Rickert ${ }^{\mathrm{b}}$, \\ a Laboratoire d'Anatomie Pathologique, Centre Hospitalier, \\ Tulle, France; ${ }^{b}$ Department of Anatomical Pathology, \\ Melbourne, Australia
}

Although medulloblastoma is the most common brain malignancy in children with an incidence of 0.6 per 100,000 personyears in children [1], it has never been reported in a fetus, an infant, a child, or an adult with Down syndrome (DS). DS is a condition identified more than 140 years ago by John Langdon Down, and is due to a supernumerary chromosome 21 [2]. The world population of persons with DS is estimated at around 5,000,000 individuals. A review of published cases of cerebral neoplasms in DS 8 years ago yielded 38 tumors [3]. Since that time, a close follow-up of the literature of clinical reports and epidemiological studies on neoplasms in DS from fetal life [4] to adulthood provided various types of benign and malignant intracranial neoplasms. These are mainly glial cell tumors and germ cell tumors, without medulloblastoma or any kind of neural cell neoplasm. Theoretically, we should observe around 30 new cases of medulloblastoma every year on the basis of the world population of persons with DS $(5,000,000)$ and the incidence of the tumor $(0.6 / 100,000$ person-years) if the incidence of medulloblastoma is similar in DS and in the general population.

The etiology of medulloblastoma remains poorly understood. No environmental factor has been clearly implicated. Genetic conditions such as Gorlin's syndrome (nevoid basal cell carcinoma syndrome) and Turcot's syndrome importantly increase the risk of developing a medulloblastoma. Molecular studies focusing on these associations allowed to unveil the role of Hedgehog and Wingless pathways in the development of the tumor $[5,6]$. Indeed, these observations lead to encouraging therapeutic results [7]. We suggest that it should as well be possible to learn more about this neoplasm by studying a condition, such as DS, which seems to strongly inhibit its development. Since it has been shown that DS also protects against another frequent embryonal neural tumor, i.e. neuroblastoma [8], we wonder whether this genetic condition could also have a protective action against neural (non-glial) neoplasms. This epidemiological observation may be related with a study on transchromosomic teratomas using mouse embryonal stem cells with a supernumerary human chromosome 21 . These trisomic teratomas showed a threefold lower percentage of neuroectodermal tissue compared to euploid teratomas. According to the authors, this demonstrates that supernumerary chromosome 21 inhibits the neurectodermal differentiation of pluripotent embryonal stem cells [9].

As biological studies must rely on clearly established facts, we would like to strongly encourage epidemiological studies to document as precisely as possible the negative link between DS and medulloblastoma

Acknowledgement

The study of tumors in DS is supported by a grant from the Fondation Jérôme Lejeune.

\section{References}

1 Central Brain Tumor Registry of the United States: Statistical Report: Primary Brain Tumors in the United States, 1998-2002. Hinsdale, Central Brain Tumor Registry of the United States, 2005.

2 Lejeune J, Gautier M, Turpin R: Study of somatic chromosomes from 9 mongoloid children. C R Hebd Seances Acad Sci 1959;248:1721-1722.

- 3 Satgé D, Monteil P, Sasco AJ, Vital A, Ohgaki H, Geneix A, Malet P, Vekemans MJ, Rethore M-O: Aspects of intracranial and spinal tumors in patients with Down syndrome and report of a rapidly progressing grade 2 astrocytoma. Cancer 2001;91:1458-1466.

4 Rickert CH, Göcke H, Paulus W: Fetal ependymoma associated with Down's syndrome. Acta Neuropathol 2002;103:78-81.

5 Taylor MD: Medulloblastoma; in Tonn JC, et al (eds): Neuro-Oncology of CNS Tumors. Berlin, Springer, 2006, pp 462-478.

-6 Polkinghorn WR, Tarbell NJ: Medulloblastoma: tumorigenesis, current clinical paradigm, and efforts to improve risk stratification. Nat Clin Pract Oncol 2007;4:295-304

7 Garber K: Hedgehog drugs begin to show results. J Natl Cancer Inst 2008;100:692-697.

-8 Satgé D, Sasco AJ, Carlsen NLT, Stiller CA, Rubie H, Hero B, De Bernardi B, De Kraker J, Coze C, Kogner P, Langmark F, Hakvoort-Cammel FGAJ, Beck D, Von Der Weid N, Parkes S, Hartmann O, Lippens RJJ, Kamps WA, Sommelet D: A lack of neuroblastoma in Down syndrome: a study from 11 European countries. Cancer Res 1998;58:448452.

-9 Mensah A, Mulligan C, Linehan J, Ruf S, O’Doherty A, Grygalewicz B, Shipley J, Groet J, Tybulewicz V, Fisher E, Brandner S, Nizetic D: An additional human chromosome 21 causes suppression of neural fate of pluripotent mouse embryonic stem cells in a teratoma model. BMC Dev Biol 2007;7:131.

Dr. Daniel Satgé

Laboratoire d'Anatomie Pathologique, Centre Hospitalier

Place Mâchat, 1012, FR-19012 Tulle (France)

Tel. +33 5552979 13, Fax +33555298605

E-Mail daniel.satge@ch-tulle.fr

\section{KARGER}

Fax +41613061234 E-Mail karger@karger.ch www.karger.com
(C) 2008 S. Karger AG, Base

$0251-5350 / 09 / 0322-0164 \$ 26.00 / 0$ 